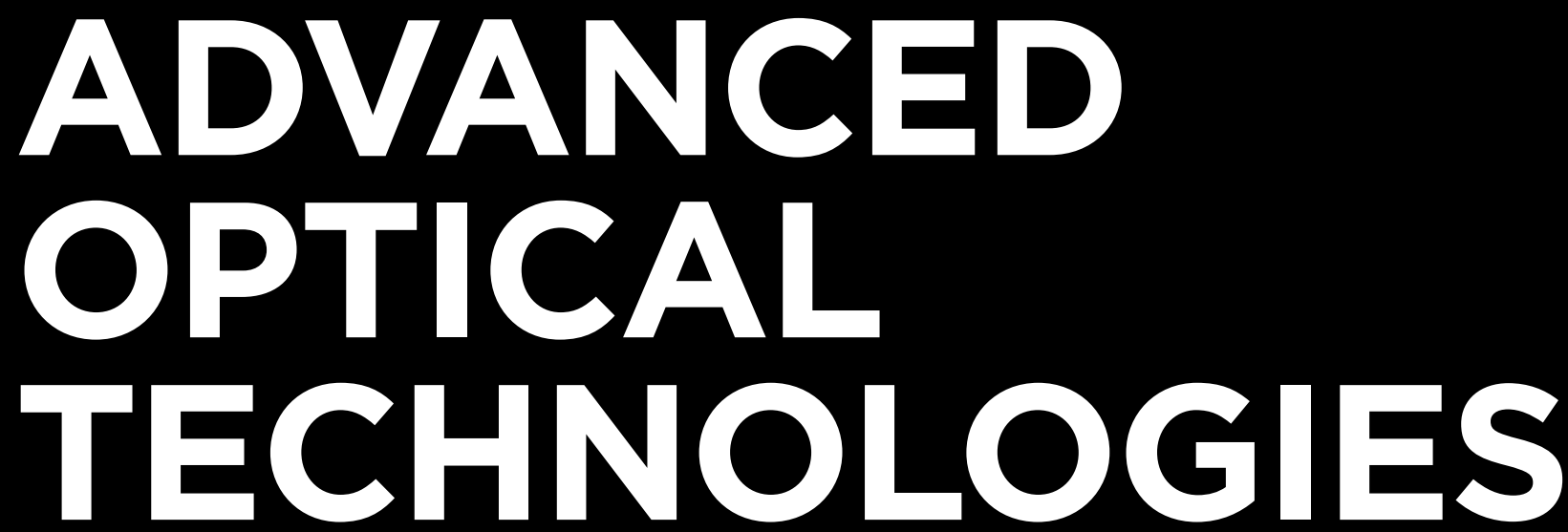

TOPICAL ISSUE:

\title{
ACTIVE IMAGING
}

\section{EDITOR-IN-CHIEF}

Michael Pfeffer

\section{GUEST EDITORS}

Martin Laurenzis

Frank Christnacher
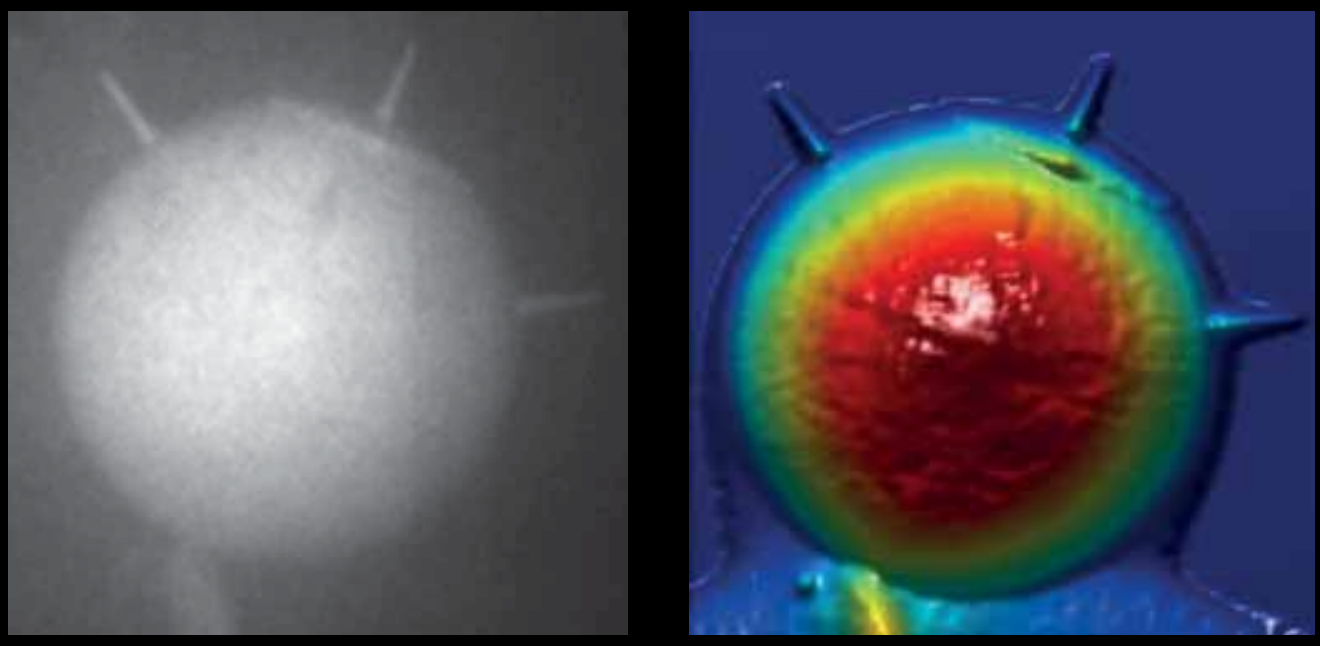


\section{ADVANCED OPTICAL TECHNOLOGIES}

EDITOR-IN-CHIEF

Michael Pfeffer, Weingarten, Germany

University of Applied Sciences Ravensburg-Weingarten, Germany

ASSOCIATE EDITOR

Allen Yi , The Ohio State University, USA

EDITORIAL BOARD

Stefan Bäumer, TNO Delft, Netherlands

Jan Burke, Fraunhofer IOSB, Germany

Andreas Erdmann, Fraunhofer IISB, Germany

Donis Flagello, Nikon RCA, USA

Michael Golub, Tel Aviv University, Israel

Norbert Kaiser, Fraunhofer IOF, Germany

Norbert Kerwien, Carl Zeiss AG, Germany

Yanqiu Li, Beijing Institute of Technology, China

Irina Livshits, St. Petersburg National Research University, Russia

Peter Loosen, Fraunhofer ILT, Germany

Angus Macleod, Thin Film Center Inc., USA

Douglas McCarter, McCarter Machine Inc., USA

Cornelius Neumann, KIT Karlsruhe, Germany

Andrew Rakich, GMTO, Germany

Jan van Schoot, ASML Netherlands BV, The Netherlands

Stefan Sinzinger, Technical University Ilmenau, Germany

Guohai Situ, Shanghai Institute of Optics and Fine Mechanics, China

Koji Sugioka, RIKEN Center for Advanced Photonics, Japan

Hugo Thienpont, Vrije Universiteit Brussel, Belgium

Hans Dieter Tholl, Diehl Defence GmbH \& Co. KG, Germany

Michael Totzeck, Carl Zeiss AG, Germany

Hexin Wang, Carl Zeiss Shanghai Co. Ltd., China

MANAGING EDITOR

Holger Kleessen, De Gruyter, Berlin, Germany

FOUNDING PUBLISHER

Andreas Thoss, THOSS Media GmbH, Berlin, Germany 
Advanced Optical Technologies is a strictly peer-reviewed scientific journal. The major aim of Advanced Optical Technologies is to publish recent progress in the fields of optical design, optical engineering, and optical manufacturing. Advanced Optical Technologies has a main focus on applied research and addresses scientists as well as experts in industrial research and development.

Advanced Optical Technologies partners with the European Optical Society (EOS). All its 4.500+ members have free online access to the journal through their EOS member account.

ABSTRACTED/INDEXED IN Astrophysics Data System (ADS) · Baidu Scholar · Celdes · Chemical Abstracts Service (CAS): CAplus; SciFinder - Clarivate Analytics: Emerging Sources Citation Index · CNKI Scholar (China National Knowledge Infrastructure) $\cdot$ CNPIEC $\cdot$ EBSCO (relevant databases) · EBSCO Discovery Service · Elsevier: Reaxys; SCOPUS · Genamics JournalSeek · Google Scholar · Inspec · J-Gate · JournalTOCs · KESLINDSL (Korean National Discovery for Science Leaders) · Naviga (Softweco) · Paperbase · Pirabase · Polymer Library · Primo Central (ExLibris) · ProQuest (relevant databases) $\cdot$ ReadCube $\cdot$ ResearchGate $\cdot$ Sherpa/RoMEO $\cdot$ Summon (Serials Solutions/ProQuest) $\cdot$ TDNet $\cdot$ TEMA Technik und Management $\cdot$ Ulrich's Periodicals Directory/ulrichsweb $\cdot$ WanFang Data $\cdot$ WorldCat (OCLC)

ISSN 2193-8576 · e-ISSN 2193-8584

All information regarding notes for contributors, subscriptions, Open access, back volumes and orders is available online at www.degruyter.com/aot

EDITOR-IN-CHIEF Michael Pfeffer, Weingarten, Germany, University of Applied Sciences Ravensburg-Weingarten, Germany, Hochschule Ravensburg-Weingarten, Doggenriedstrasse, Postfach 1261, 88241 Weingarten, Germany, Tel.: +49 (0)751 501 9539, Fax: +49 (0)751 501 9874, Email: michael.pfeffer@hs-weingarten.de

MANAGING EDITOR Holger Kleessen, De Gruyter, Genthiner Straße 13, 10785 Berlin, Germany, Tel.: +49 (0)30 260 05-348, Fax: +49 (0)30 260 05-250, Email: holger.kleessen@ degruyter.com

FOUNDING PUBLISHER Andreas Thoss, THOSS Media GmbH, Wolfshagener Str. 56, 13187 Berlin, Germany, Email: th@ thoss-media.com

RESPONSIBLE FOR ADVERTISEMENTS Claudia Neumann, De Gruyter, Genthiner Straße 13, 10785 Berlin, Germany. Tel.: +49 (0)30 260 05-226, Fax: +49 (0)30 260 05-322, Email: anzeigen@ degruyter.com

(C) 2019 Walter de Gruyter GmbH, Berlin/Boston and THOSS Media GmbH

TYPESETTING Compuscript Ltd., Shannon, Ireland

PRINTING Franz X. Stückle Druck und Verlag e.K., Ettenheim

Cover image: 2D-intensity image from underwater laser gated viewing and post processed 3D reconstruction of a mine model. See also article on page 461. Images published with courtesy of the French-German Research Institute of Saint-Louis (ISL) and the Technical Centre for Ships and Naval Weapons, Maritime Technology and Research (WTD 71).

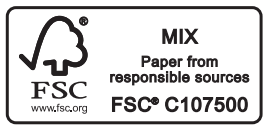




\section{Contents}

\section{Views}

Frank Christnacher, Martin Laurenzis, Yves Lutz and Alexis Matwyschuk

Sixty years of advanced imaging at the French-German Research Institute of Saint-Louis: from the CranzSchardin camera to computational optics - 403

\section{Community}

Conference Notes -415

EOS News -419

Conference Calendar -420

\section{Topical Issue}

\section{Active Imaging \\ Guest Editors: Martin Laurenzis, Frank Christnacher}

\section{Editorial}

Martin Laurenzis and Frank Christnacher

Active imaging - 423

\section{Review Article}

Vasyl Molebny

Nick-named laser radars -425

\section{Research Articles}

Yves Lutz, Alexis Matwyschuk and Jean-Michel Poyet Experimental SWIR gated viewing in accumulation mode -437

Frank Rutz, Rolf Aidam, Henning Heußen, Wolfgang Bronner, Robert Rehm, Matthias Benecke, Alexander Sieck, Simon Brunner, Benjamin Göhler and Peter Lutzmann

InGaAs APD matrix sensors for SWIR gated viewing - 445

Olivier Meyer

Modelling and impact of the turbulence effect on flash and cumulative $2 \mathrm{D}$ active imaging system -451
Thomas Scholz, Martin Laurenzis and Frank Christnacher Laser-based imaging applications in turbid waters -461

\section{Review Article}

Andreas Bielawny

Reflectors in lighting design -469

\section{Research Articles}

Dennis Zimmermann, Andreas Beutler, Matthias Brozio, Simon Freutel, Philipp Kosse and Cornelius Neumann A procedure for designing and manufacturing microstructured lenses used in automotive headlamps - 483

Na Yang, Chiemi Oka, Seiichi Hata and Junpei Sakurai Fabrication of textured substrates for dye-sensitized solar cells using polydimethylsiloxane nanoimprint lithography - 491

Frederico Lima, Isman Khazi, Ulrich Mescheder, Alok C. Tungal and Uma Muthiah

Fabrication of 3D microstructures using grayscale lithography -499

Dali Ramu Burada, Kamal K. Pant, Vinod Mishra, Mohamed Bichra, Gufran Sayeed Khan, Stefan Sinzinger and Chandra Shakher

Development of a metrology technique suitable for in situ measurement and corrective manufacturing of freeform optics - 513

Hefei Zhou, Xiaoyang Zhu, Hongke Li and Hongbo Lan Fabrication of the large-area flexible transparent heaters using electric-field-driven jet deposition micro-scale 3D printing -527

\section{Erratum}

Razvan Stoian, Manoj K. Bhuyan, Guodong Zhang, Guanghua Cheng, Remy Meyer and Francois Courvoisier Erratum to: Ultrafast Bessel beams: advanced tools for laser materials processing -535 